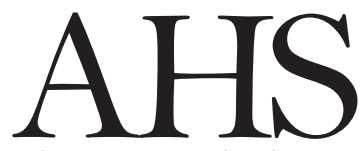

Advances in Horticultural Science

\title{
Growth response nitrogen metabolism of grafted cucumber fertilized with different ratios of nitrate: ammonium fertilizer
}

\author{
M. Haghighi ${ }^{1}{ }^{(*)}$, O. Zamani ${ }^{1}$, L. Abbey ${ }^{2}$ \\ 1 Department of Horticulture, College of Agriculture, Isfahan University \\ of Technology, Isfahan, Iran. \\ 2 Department of Plant, Food, and Environmental Sciences, Faculty of \\ Agriculture, Dalhousie University, 50 Pictou Road, PO Box 550, Truro, \\ B2N 5E3, Nova Scotia, Canada.
}

OPEN ACCESS

Key words: Endemic accession, nutrient absorption, $\mathrm{N}$ metabolism, photosynthesis.

(*) Corresponding author:

mhaghighi@iut.ac.ir

Citation:

HAGHIGHI M., ZAMANI O., ABBEY L., 2021 Growth response nitrogen metabolism of grafted cucumber fertilized with different ratios of nitrate: ammonium fertilizer. - Adv. Hort. Sci., 35(2): 165-174

\section{Copyright:}

(C) 2021 Haghighi M., Zamani O., Abbey L. This is an open access, peer reviewed article published by Firenze University Press

(http://www.fupress.net/index.php/ahs/) and distributed under the terms of the Creative Commons Attribution License, which permits unrestricted use, distribution, and reproduction in any medium, provided the original author and source are credited.

Data Availability Statement:

All relevant data are within the paper and its Supporting Information files.

Competing Interests:

The authors declare no competing interests.

Abstract: The use of an endemic plant as rootstock has many merits but its application for cucurbits production has not been extensively investigated. The present study determined the growth responses of grafted cucumber using two endemic rootstocks from Cucurbita pepo L. fertilized with different ratios of nitrate $\left(\mathrm{NO}_{3}{ }^{-}\right)$: ammonium $\left(\mathrm{NH}_{4}{ }^{+}\right)$fertilizer. A greenhouse study was carried out using cucumber (C. sativus 'Dominos') grafted on two accessions of Cucurbita pepo L. collected from Babol and Isfahan with the control being ungrafted $C$. sativus 'Dominos'. Different ratios of $\mathrm{NO}_{3}{ }^{-} / \mathrm{NH}_{4}{ }^{+}$as follows: 100:0 ( $\mathrm{NO}_{3}{ }^{-}$alone), $25 / 75,50 / 50,75 / 25$ and $0 / 100\left(\mathrm{NH}_{4}{ }^{+}\right.$alone) were applied. It was found that different rootstock has the same physiology but different growth attributes. The growth of the ungrafted cucumber was lower than the grafted ones, and Babol showed better or equal growth compared to the Isfahan rootstock. The $\mathrm{NO}_{3}$ $/ \mathrm{NH}_{4}{ }^{+}$effect on growth of the cucumber shoot and root fresh and dry weights, root and shoot lengths, nodes, and number of leaves were increased in the $75 / 25$ ratio compared to the other treatments. Grafting on the Isfahan and Babol showed the same effect of $\mathrm{N}$ metabolism i.e., grafting increased nitrate reductase activity and $\mathrm{NO}_{3}{ }^{-}$concentration in the 75/25 and the 100/0. Protein content and amino acids content of leaves increased in the grafted cucumber treated with $50 / 50 \mathrm{NO}_{3}-\mathrm{NH}_{4}{ }^{+}$. The same response of photosynthesis parameters was observed in the different rootstocks. In conclusion, the result suggested that the grafted 'Dominos' on Babol endemic rootstock at $50 / 50 \mathrm{NO}_{3}-\mathrm{NH}_{4}^{+}$ ratio gave the high growth.

\section{Introduction}

Grafting is a horticultural technique performed by joining two plants i.e., a scion and a rootstock. Grafting of plants can minimize the detrimental effects of biotic and abiotic stress if the proper rootstock is used (Lee 
and Oda, 2003; Rouphael et al., 2008; Keshavarzi and Shekafandeh, 2019). Many studies have shown that grafting promotes root and shoot growth, increase plant resistance against diseases, increase plant tolerance to temperature extremities and soil salinity, increase nutrient and water absorption, and plant productivity (Colla et al., 2010; Lee et al., 2010). Nutrient uptake like nitrogen $(\mathrm{N})$ and phosphorus $(\mathrm{P})$ absorptions improved by grafting of cucumber to fig leaf gourd (Cucurbita ficifolia L.) (Pogonyi et al., 2005).

Cucumber 'Adrian' was grafted onto three rootstocks of Lagenaria siceraria, Cucurbita maxima $\times$ C. moschata, and zucchini. Results showed that grafting improved total yield, leaves number, total soluble solids and titratable acidity.

The effect of grafting is highly dependent on the choice of rootstock (Goreta et al., 2014 ; Dadashpour et al., 2017) to improve growth and fruit production. The benefits of grafting on vegetative growth have been reported for cucurbit-type crops (Goreta et al., 2014) but using the endemic cucurbits as a rootstock for this family has not been extensively investigated.

Ammonium, nitrate and urea are the three forms of inorganic nitrogen that increase plant growth (Niu et al., 2011). Most plants prefer nitrate to ammonium or a combination of them. The optimal $\mathrm{NO}_{3}{ }^{-} / \mathrm{NH}_{4}{ }^{+}$ ratio depends on many factors such as plant species, plant growth and maturity stages, and environment condition (Marschner, 2012). Yet, little is known about how the $\mathrm{NO}_{3}-\mathrm{NH}_{4}{ }^{+}$ratio may affect grafted plant and their nitrogen metabolism.

Higher $\mathrm{NO}_{3}{ }^{-} / \mathrm{NH}_{4}{ }^{+}$ratio produce higher biomass than other ratios in mesquite (Prosopis velutina) (Hahne and Schuch, 2006). Conversely, higher $\mathrm{NO}_{3}$ improves growth and flowering in Phalaenopsis orchid (Phalaenopsis) (Wang et al., 2008). In some plants, $\mathrm{N}$ form has no significant effects on growth. For instance, the dry weight of shoots and roots, and root/shoot ratio were not affected by $\mathrm{NO}_{3}{ }^{-} / \mathrm{NH}_{4}{ }^{+}$ratio in Sophora secundiflora (Niu et al., 2011). However, using high $\mathrm{NO}_{3}^{-}$in plant nutrition is a risk for the environment and human health. Replacing $\mathrm{NO}_{3}^{-}$in plant nutrition with an appropriate amount of $\mathrm{NH}_{4}+$ may alleviate these concerns. Plants usually grow on $\mathrm{NO}_{3}$ and $\mathrm{NH}_{4}^{+}$as nitrogen sources, which eventually influence the synthesizing of amino acids and proteins (Xing et al., 2015).

The optimum level of $\mathrm{N}$ and the best ratio of $\mathrm{NO}_{3}$ $/ \mathrm{NH}_{4}{ }^{+}$are required by each species according to their respective growth and productivity (Fernandez-Nava et al., 2010). On the other hand, the process of up taking $\mathrm{NO}_{3}$ - or $\mathrm{NH}_{4}^{+}$has a substantial impact on the uptake of other cations and anions and rhizosphere$\mathrm{pH}$. When roots take up $\mathrm{NO}_{3}{ }^{-}$with a negative charge and $\mathrm{NH}_{4}^{+}$with a positive charge, they release a specific charged molecule to keep a balanced $\mathrm{pH}$ inside the plant cells. $\mathrm{NH}_{4}^{+}$reduces rhizosphere $\mathrm{pH}$ while $\mathrm{NO}_{3}{ }_{3}^{-}$ increases pH (Marschner, 2012). High levels of $\mathrm{NH}_{4}^{+}$ can also inhibit the uptake of cations such as calcium and magnesium (Siddiqi et al., 2002).

Ammonium application reduces the rate of iron deficiency but increases phosphate and sulfate uptake due to changing substrate $\mathrm{pH}$. In contrast, nitrate reduces the absorption of those essential anions. Thus, most of the time, supplying the proper $\mathrm{NO}_{3}{ }^{-} / \mathrm{NH}_{4}{ }^{+}$ratio results in the highest growth rates and plant yield by balancing nutrient absorption (Marschner, 2012).

Cucumber has a shallow root system and could not uptake nutrient well (Causin et al., 2004). Information on the influence of endemic accession as a rootstock on cucumber nutrient absorption and growth is limited. To better understand the effect of $\mathrm{NO}_{3}{ }^{-} / \mathrm{NH}_{4}{ }^{+}$ratio for grafted cucumber, the present study was designed. The present study determined plant growth response of grafted cucumber using two endemic rootstocks from Cucurbita pepo L. fertilized with different ratios of $\mathrm{NO}_{3}{ }^{-} / \mathrm{NH}_{4}{ }^{+}$under greenhouse conditions.

\section{Materials and Methods}

Production of rafte seedlings and experimenta design

The greenhouse experiment was carried out at the Isfahan University of Technology, Isfahan, Iran. Cucurbita pepo L. accession as the rootstocks were collected from the Babol (Babol), Isfahan region (Isfahan), and C. sativus 'Dominos' is a common cultivar used as scion. The ungrafted Dominos used as control. Total nitrogen in the nutrient solution was equal and comprised $\mathrm{NO}_{3}{ }^{-} / \mathrm{NH}_{4}{ }^{+}$ratio 100:0, 25:75, $50: 50,75: 25$, or $0: 100$. Rootstock and scion seeds were sown in cocopeat and perlite $(50 / 50 \mathrm{v} / \mathrm{v})$. Scion seeds had been cultured 10 days before the rootstock seeds in cocopeat: perlite ratio of $1: 1$. Scion plants and rootstocks were cut beneath and above the first true leaves, respectively. The hole insertion grafting method as described by Lee (1994) was adopted. Firstly, true leaves and meristem tissue were removed at the growing tip of the rootstock 
before making a slit across the growing point from the bottom of one cotyledon to the other side of the hypocotyl. The newly grafted cucumber plant was kept in a grafting chamber with approximately $65 \%$ relative humidity and exposed at $16 \mathrm{~h}$ fluorescent light at $25-30^{\circ} \mathrm{C}$ for two weeks. The grafted plants were moved to the greenhouse and maintained at $30-35^{\circ} \mathrm{C}$ and $60-65 \%$ relative humidity for one week to gradually adapt to the greenhouse conditions (Kashi et al., 2008). Fertilization with a half-modified Johnson nutrient solution was applied to the grafted plants including (mM): $\mathrm{MgSO}_{4}(2), \mathrm{KH}_{2} \mathrm{PO}_{4}(1), \mathrm{H}_{3} \mathrm{BO}_{3}$ (50), $\mathrm{MnCl}_{2}(10), \mathrm{CaCl}_{2}(1), \mathrm{MnSO}_{4}$ (10), $\mathrm{CuSO}_{4}$ (1.5), $\mathrm{ZnSO}_{4}(0.8), \mathrm{Na}_{2} \mathrm{MoO}_{4}(0.4), \mathrm{Co}\left(\mathrm{NO}_{3}\right)_{2}(0.1), \mathrm{KNO}_{3}(10)$, $\mathrm{FeCl}_{3}(0.1)$, EDTA (0.3) and $\mathrm{H}_{3} \mathrm{BO}_{3}$ (50.5) mM (Jones, 2005). Ten (10) days after adaptation of the grafted plants, they were treated with the $\mathrm{NO}_{3}{ }^{-} / \mathrm{NH}_{4}{ }^{+}$ratios on a daily basis. The control treatment was irrigated with a complete Johnson nutrient solution. The plants were kept in the nutrient solution at varying $\mathrm{NO}_{3}{ }^{-} / \mathrm{NH}_{4}{ }^{+}$ratios with $5 \mathrm{~min}$ airing in every $15 \mathrm{~min}$ in 2 liter container. The $\mathrm{EC}$ and $\mathrm{pH}$ of the nutrient solution were kept at $2.0 \pm 0.2 \mathrm{dS} \mathrm{m}^{-1}$ and $6.0 \pm 0.3$, respectively, by adding $\mathrm{HNO}_{3}$ and $\mathrm{H}_{3} \mathrm{PO}_{4}$ into the nutrient solution. Plants were maintained for six more weeks before final harvest.

\section{Data collection}

Greenness. Chlorophyll index was measured with portable SPAD (SPAD-502 plus, Minolta, Japan).

Growth trait assay. All the leaf and nod number were counted. The shoots of seedlings were separated from the roots and after recording the fresh weight, they were oven dried at $70^{\circ} \mathrm{C}$ to constant weight. Root volume was measured by change in water volume in a graduated container (Haghighi et al., 2012). Shoot and root length measured by ruler and the stem thickness was measured using a pair of caliper.

Photosynthesis traits assay. Gas exchange parameters including photosynthesis rate, transpiration, stomata conductivity, and intercellular $\mathrm{CO}_{2}$ of stomata were measured by a portable photosynthesis meter (Li-Cor Li-3000, USA) on a sunny day. Photosynthetically active radiation (PAR) intensity was $1000 \mu \mathrm{mol} \mathrm{m} \mathrm{m}^{-2} \cdot \mathrm{s}^{-1}$ and $\mathrm{CO}_{2}$ concentration was $350 \mu \mathrm{mol} \cdot \mathrm{mol}$. The same leaves of each plant was used for chlorophyll measurement using chlorophyll meter (SPAD-502, Minolta Corp., NJ, USA). Mesophyll conductance ( $\mathrm{mmol} \mathrm{CO}_{2} \mathrm{~m}^{-2} \mathrm{~s}^{-1}$ ) was measured according by using the formula: Photosynthetic rate/sub-stomatal $\mathrm{CO}_{2}$ concentration (Ahmadi and Siosemardeh, 2005).

Phenolic content. The Folin-Ciocalteu method was used for measuring the total phenolic content of the root exudate. The absorbance was measured at 725 $\mathrm{nm}$ with a spectrophotometer (UV 160A- Shimadzu Corp., Kyoto, Japan) (Motamedi et al., 2019).

Prolin. Plant leaves were homogenized in 3\% sulfosalicylic acid at $4^{\circ} \mathrm{C}$. Then the solution incubated and centrifuged at $5000 \mathrm{rpm}$ for $20 \mathrm{~min}$. The supernatant was mixed with $2.5 \%$ ninhydrin, $60 \%$ phosphoric acid ( $\mathrm{v} / \mathrm{v}$ ) and $1 \mathrm{ml}$ of glacial acetic acid (100\%). The absorbance was measured at $518 \mathrm{~nm}$ by spectrophotometer (UV 160A-Shimadzu Corp., Kyoto, Japan) (Bates et al., 1973).

Total amino acid. Total amino acids measured by high-performance liquid chromatography (HPLC). Samples were hydrolyzed with $6 \mathrm{M} \mathrm{HCl}$ and $10 \mathrm{mg}$ phenol (for protection of tyrosine) at $110{ }^{\circ} \mathrm{C}$ for $24 \mathrm{~h}$. HPLC system was equipped with MD-1510 diodearray detector and set to $263 \mathrm{~nm}$ ( $\lambda$ max). The samples were injected with a $20 \mu \mathrm{L}$ loop using a 7125 valve (Rheodyne, Cotati, CA) onto a Purospher RP-18 column and operated at $25^{\circ} \mathrm{C}$ with a flow rate of 1.0 $\mathrm{mL} / \mathrm{min}$ using $50 \mathrm{mM}$ acetate buffer $(\mathrm{pH} \mathrm{4.2)}$ as eluent $\mathrm{A}$ and acetonitrile as eluent B (El-Abagy et al., 2014). The level of amino acids present in $100 \mathrm{~g}$ of leaves.

Protein. Na-phosphate buffer ( $\mathrm{pH} 7.2)$ was used to homogenized $1 \mathrm{~g}$ fresh leaf samples then centrifuged at $4^{\circ} \mathrm{C}$. The absorbance of the supernatants and dye measured using a spectrophotometer (UV 160AShimadzu Corp., Kyoto, Japan) at $595 \mathrm{~nm}$. Bovine serum albumin (BSA) used as protein standard (Bradford, 1976).

Nitrate reductase enzyme. The activity of nitrate reductase enzyme was measured according to the method proposed by (Cazetta and Villela, 2004). The amount of $400 \mathrm{mg}$ of leaf samples was placed in a phosphate solution (100 mg, $\mathrm{pH}=7.5$ ) containing $4 \%$ propanol and potassium nitrate, and stored in darkness for an hour at a temperature of $30^{\circ} \mathrm{C}$. Then, 1 $\mathrm{mL}$ of the solution containing sulfanilic acid was dissolved in $2 \mathrm{ml}$ of chloride acid and $1 \mathrm{~mL}$ of naphthylethylene diamide solution (0.02\%) and after 20 min, the absorbance was measured at $540 \mathrm{~nm}$ wavelength.

Sodium nitrite $\left(\mathrm{NaNO}_{3}\right)$ was used to prepare the standard solution and the enzyme activity was calculated based on $\mu \mathrm{mol}$ nitrite/gr FW h. 
Nitrate concentration. The leaf nitrate content was determined following the procedures described by Atanasova (2008).

Nutrient concentrations. The amount of calcium was measured by an atomic absorption device (model: Perkin Elmer, AA200) (Sharifi et al., 2016). zK concentration was determined by atomic absorption after digestion with $\mathrm{HCl}$ (Murillo-Amador et al., 2007). Nitrogen concentration of leaves measured by Kjeldahl method. Phosphorus was estimated by the vanadomolybdo phosphoric acid colorimetric method at $460 \mathrm{~nm}$ (Estan et al., 2005).

$\mathrm{Ca}$ concentrations. Twelve fruits for each treatment when reached market ripe harvested at the end of the experiment for measurements. Four leaf samples, consisting of young, fully expanded leaves were collected, washed thoroughly with tap water, gave a final rinsing with deionized water, dried at $65^{\circ} \mathrm{C}$ to constant weight. The extraction of Ca from the plant tissue material was performed using $1 \mathrm{~N}$ $\mathrm{HCl}$ after dry ashing at $550^{\circ} \mathrm{C}$ for five $\mathrm{h}$. The amount of calcium was measured by an atomic absorption device (model: Perkin Elmer, AA200) (Sharifi et al., 2014).

$K, \mathrm{Mg}$, and $\mathrm{P}$ concentrations. The concentrations of $\mathrm{K}, \mathrm{Mg}$, and $\mathrm{P}$ were measured (Shield Torch System,
Agilent 7500a). Meanwhile, phosphorus was estimated by the vanadomolybdo phosphoric acid colorimetric method at $460 \mathrm{~nm}$ (Sharifi et al., 2014). P was colorimetrically determined using a spectrophotometer (UV 160A-Shimadzu Corp., Kyoto, Japan).

\section{Statistical analysis}

The factorial experiment was arranged in a completely randomized design with 10 replications. Data were analyzed with Statestix 8 (Tallahassee FL, USA) and treatment means were separated using the least significant difference (LSD) test at the $5 \%$ level of significance when the analysis of variance indicated significant difference between treatments at $P \leq 0.05$.

\section{Results}

The ANOVA in Table 1 showed that all growth and development characteristics were affected by $\mathrm{NO}_{3}$ $/ \mathrm{NH}_{4}{ }^{+}$ratio and rootstock.

The interaction of $\mathrm{NO}_{3}{ }^{-} / \mathrm{NH}_{4}{ }^{+}$ratio and rootstock significantly affected all measured variables except rootstock stem thickness and root volume. Except for leaf greenness, all physiological parameters were affected by $\mathrm{NO}_{3}-/ \mathrm{NH}_{4}^{+}$ratio and rootstock and their interaction (Table 2).

Table 1 - Analysis of variance effect of $\mathrm{NO}_{3}: \mathrm{NH}_{4}$ ratio a rootstock on growth characteristics of cucumber

\begin{tabular}{lcccccccccc}
\hline Source & df & $\begin{array}{c}\text { Shoot } \\
\text { length }\end{array}$ & $\begin{array}{c}\text { Rootstock } \\
\text { stem } \\
\text { thickness }\end{array}$ & $\begin{array}{c}\text { Number } \\
\text { scion } \\
\text { leaves }\end{array}$ & $\begin{array}{c}\text { Number } \\
\text { scion } \\
\text { nodes }\end{array}$ & $\begin{array}{c}\text { Shoot } \\
\text { fresh } \\
\text { weight }\end{array}$ & $\begin{array}{c}\text { Root } \\
\text { fresh } \\
\text { weight }\end{array}$ & $\begin{array}{c}\text { Root } \\
\text { volume }\end{array}$ & $\begin{array}{c}\text { Root } \\
\text { length }\end{array}$ & $\begin{array}{c}\text { Shoot } \\
\text { dry } \\
\text { weight }\end{array}$ \\
\hline $\mathrm{NO}_{3}: \mathrm{NH}_{4}$ ratio (N) & 4 & $59.92^{* *}$ & $3.03^{* *}$ & $7.23 * *$ & $12.88^{* *}$ & $24.69 * *$ & $1.08^{* *}$ & $2.44^{* *}$ & $100.49 * *$ & $0.06 * *$ \\
Rootstock (R) & 2 & $290.70^{* *}$ & $6.51 * *$ & $36.87 * *$ & $24.01 * *$ & $14.03 *$ & $1.16^{* *}$ & $2.94 * *$ & $92.88^{* *}$ & $0.26 * *$ \\
$\mathrm{NxR}$ & 8 & $37.40^{* *}$ & $1.67 \mathrm{~ns}$ & $6.19 * *$ & $4.03 *$ & $24.73 * *$ & $0.64 * *$ & $2.04 \mathrm{~ns}$ & $44.01 * *$ & $0.09 * *$ \\
Error & 30 & 26.78 & 0.40 & 3.44 & 1.60 & 3.40 & 0.05 & 0.11 & 5.07 & 0.01 \\
$\mathrm{CV}$ & & 20.31 & 14.22 & 28.98 & 20.89 & 31.31 & 38.97 & 39.76 & 18.63 & 24.10 \\
\hline
\end{tabular}

NS, $* * *$ not significant, significant at $5 \%$ or $1 \%$, respectively.

Table 2 - Analysis of variance effect of $\mathrm{NO}_{3}: \mathrm{NH}_{4}$ ratio on physiological characteristics of cucumber

\begin{tabular}{|c|c|c|c|c|c|c|c|c|c|c|c|c|c|}
\hline Source & $\mathrm{df}$ & Greeness & $\begin{array}{l}\text { Photo- } \\
\text { synthesis }\end{array}$ & $\begin{array}{c}\text { Tran- } \\
\text { spiration }\end{array}$ & $\begin{array}{c}\text { Inter- } \\
\text { cellular } \mathrm{CO}_{2} \\
\text { concentra- } \\
\text { tion of } \\
\text { stomata }\end{array}$ & $\begin{array}{c}\text { Stomata } \\
\text { conductivity }\end{array}$ & $\begin{array}{c}\text { Meso- } \\
\text { philic } \\
\text { conductivity }\end{array}$ & $\begin{array}{l}\text { Nitrate } \\
\text { reductase } \\
\text { activity }\end{array}$ & Proline & $\begin{array}{c}\text { Root } \\
\text { phsenol }\end{array}$ & Protein & Nitrate & $\begin{array}{l}\text { Amino } \\
\text { acid }\end{array}$ \\
\hline $\mathrm{NO}_{3}: \mathrm{NH}_{4}$ ratio $(\mathrm{N})$ & 4 & $14.34 \mathrm{NS}$ & $9.59 \mathrm{NS}$ & 3.01 NS & 19146.7 NS & 0.0041 NS & 0.0051 NS & 0.006 NS & 2.33 NS & 1.61 NS & 3307 NS & 0.0000013 NS & 35460 NS \\
\hline Rootstock ( R) & 2 & 3.19 NS & 11.17 NS & 1.97 NS & 34138.4 NS & 0.0043 NS & 0.0033 NS & 0.013 NS & 1.77 NS & $1.56 \mathrm{NS}$ & 29073 NS & $0.000075 \mathrm{NS}$ & 251790 NS \\
\hline$N \times R$ & 8 & $23.42 * *$ & $19.16 * *$ & $4.11 * *$ & $13750.9 * *$ & $0.005 * *$ & $0.005 * *$ & $0.003 * *$ & $2.39 * *$ & $2.05 * *$ & $59005 * *$ & $0.000015 * *$ & $236095 * *$ \\
\hline Error & 22 & 0.92 & 9.17 & 9.17 & 9.17 & 9.17 & 9.19 & 9.17 & 9.18 & 9.17 & 30518 & 0.000043 & 72919 \\
\hline $\mathrm{CV}$ & 38 & 12.52 & 4.69 & 7.41 & 3.23 & 0.16 & 0.15 & 0.02 & 0.65 & 0.08 & 17.18 & 11.08 & 24.17 \\
\hline
\end{tabular}

NS, $* * *$ not significant or significant at $5 \%$ or $1 \%$. 
The main effect of nutrient absorbtion was not affected by $\mathrm{NO}_{3}-\mathrm{NH}_{4}^{+}$ratio and rootstock, but the interaction showed significant changes (Table 3 ).

The main result of the $\mathrm{N}$ source indicated that the thickest rootstock stem was at $75 / 25 \mathrm{NO}_{3}{ }^{-} / \mathrm{NH}_{4}{ }^{+}$ratio and the most significant root volume was influenced by treatment $50 / 50 \mathrm{NO}_{3}-\mathrm{NH}_{4}{ }^{+}$ratio. The ungrafted plants had the least root volume and Babol has the most root volume (Table 4).

Shoot length increased when the ratio of $\mathrm{NO}_{3}$ $/ \mathrm{NH}_{4}{ }^{+}$increased, which led to higher $\mathrm{NO}_{3}^{-}$in shoot length compared to the root length (Fig. $1 \mathrm{~A}$ and $\mathrm{B}$ ). The shoot length was highest in the $0 / 100$ and then in the $75 / 25$ of $\mathrm{NO}_{3}^{-} / \mathrm{NH}_{4}^{+}$ratio in all rootstock. It seemed the root had the best growth in the 50/50 $\mathrm{NO}_{3}{ }^{-} / \mathrm{NH}_{4}{ }^{+}$ratio, and when the $\mathrm{NO}_{3}{ }^{-} / \mathrm{NH}_{4}{ }^{+}$ratio was increased by more than $75 \%$ of total- $\mathrm{N}$, the root length decreased.

Shoot and root fresh and dry weights were not

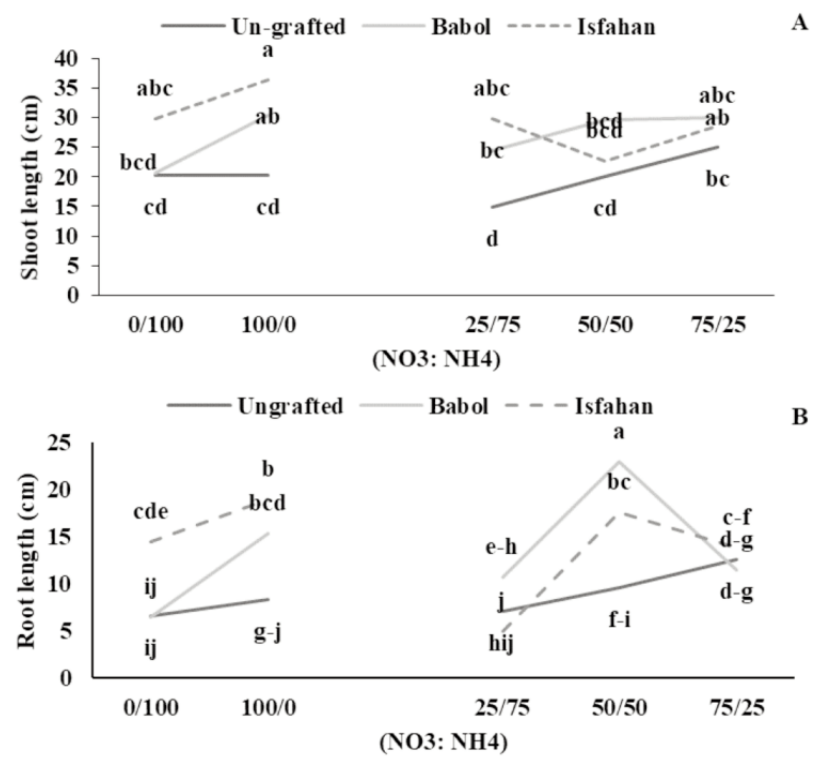

Fig. 1 - The interaction effect of different rootstocks and $\mathrm{NO}_{3}: \mathrm{NH}_{4}$ ratio on $\mathrm{A}$ ) shoot length and $\mathrm{B}$ ) root length.

Table 3 - Analysis of variance effect of $\mathrm{NO}_{3}: \mathrm{NH}_{4}$ ratio on nutrient concentration of cucumber

\begin{tabular}{lcccccc}
\hline Source & df & $\begin{array}{c}\mathrm{N} \\
\text { concentration }\end{array}$ & $\begin{array}{c}\mathrm{P} \\
\text { concentration }\end{array}$ & $\begin{array}{c}\mathrm{K} \\
\text { concentration }\end{array}$ & $\begin{array}{c}\mathrm{Ca} \\
\text { concentration } \\
\text { concentration }\end{array}$ \\
\hline $\mathrm{NO}_{3}: \mathrm{NH}_{4}$ ratio (N) & 4 & $230.9 \mathrm{NS}$ & $244.56 \mathrm{NS}$ & $43.12 \mathrm{NS}$ & $78.12 \mathrm{NS}$ & $6.12 \mathrm{NS}$ \\
Rootstock (R) & 2 & $23.45 \mathrm{NS}$ & $150.01 \mathrm{NS}$ & $35.93 \mathrm{NS}$ & $602.45 \mathrm{NS}$ & $13.08 \mathrm{NS}$ \\
$\mathrm{N} \times \mathrm{R}$ & 8 & $26.54 * *$ & $111.77 * *$ & $4.65 * *$ & $81.12 * *$ & $4.20 *$ \\
Error & 22 & 5.27 & 67.38 & 3.23 & 76.32 & 1.35 \\
$\mathrm{CV}$ & 38 & 25.62 & 13.04 & 15.50 & 23.97 & 44.38 \\
\hline
\end{tabular}

NS, $* * *$ not significant, significant at $5 \%$ or $1 \%$, respectively.

Table 4 - Effects of $\mathrm{NO}_{3}: \mathrm{NH}_{4}$ ratio and rootstocks on root volume and cucumber rootstock stem

\begin{tabular}{lcc}
\hline Treatments & $\begin{array}{c}\text { Rootstock stem } \\
\text { thickness } \\
(\mathrm{cm})\end{array}$ & $\begin{array}{c}\text { Root } \\
\text { volume } \\
\left(\mathrm{mm}^{3}\right)\end{array}$ \\
\hline $\mathrm{NO}_{3}: \mathrm{NH}_{4}$ ratio & $4.51 \mathrm{~b}$ & \\
$100 / 0$ & $3.62 \mathrm{c}$ & $0.35 \mathrm{c}$ \\
$25 / 75$ & $4.50 \mathrm{~b}$ & $0.47 \mathrm{bc}$ \\
$50 / 50$ & $5.46 \mathrm{a}$ & $1.85 \mathrm{a}$ \\
$75 / 25$ & $4.40 \mathrm{~b}$ & $0.80 \mathrm{~b}$ \\
$0 / 100$ & & $0.78 \mathrm{~b}$ \\
Rootstock & $3.71 \mathrm{~b}$ & \\
Un-grafted & $4.66 \mathrm{a}$ & $0.49 \mathrm{~b}$ \\
Babol & $5.13 \mathrm{a}$ & $1.40 \mathrm{a}$ \\
Isfahan & & $0.67 \mathrm{~b}$ \\
\hline
\end{tabular}

NS, $*, * *$ not significant or significant at $5 \%$ or $1 \%$. improved with only $\mathrm{NO}_{3}^{-}$or $\mathrm{NH}_{4}{ }^{+}$(Fig. 2A-D). The Babol rootstock caused the best shoot and root growth in the $50 / 50 \mathrm{NO}_{3}{ }^{-} / \mathrm{NH}_{4}{ }^{+}$ratio. Ungrafted plant showed the lower growth in all the treatment $\mathrm{N}$ ratios. It seemed that the different $\mathrm{NO}_{3}{ }^{-} / \mathrm{NH}_{4}{ }^{+}$ratio did not affect the growth in ungrafted plants. Isfahan rootstock increased both shoot and root growth in the $75 / 25 \mathrm{NO}_{3}{ }^{-} / \mathrm{NH}_{4}{ }^{+}$ratio. The highest root and shoot growth were seen in the Babol and the 50/50 $\mathrm{NO}_{3}{ }^{-} / \mathrm{NH}_{4}{ }^{+}$ratio compared to all the other treatments.

The numbers nodes and leaves increased by increasing the $\mathrm{NO}_{3}^{-}$portion of the nutrient solution for the grafted plants, but there were no significant changes in the ungrafted plants in the different $\mathrm{NO}_{3}-$ $/ \mathrm{NH}_{4}^{+}$ratios (Fig. $3 \mathrm{~A}$ and $\mathrm{B}$ ). The lowest number of 

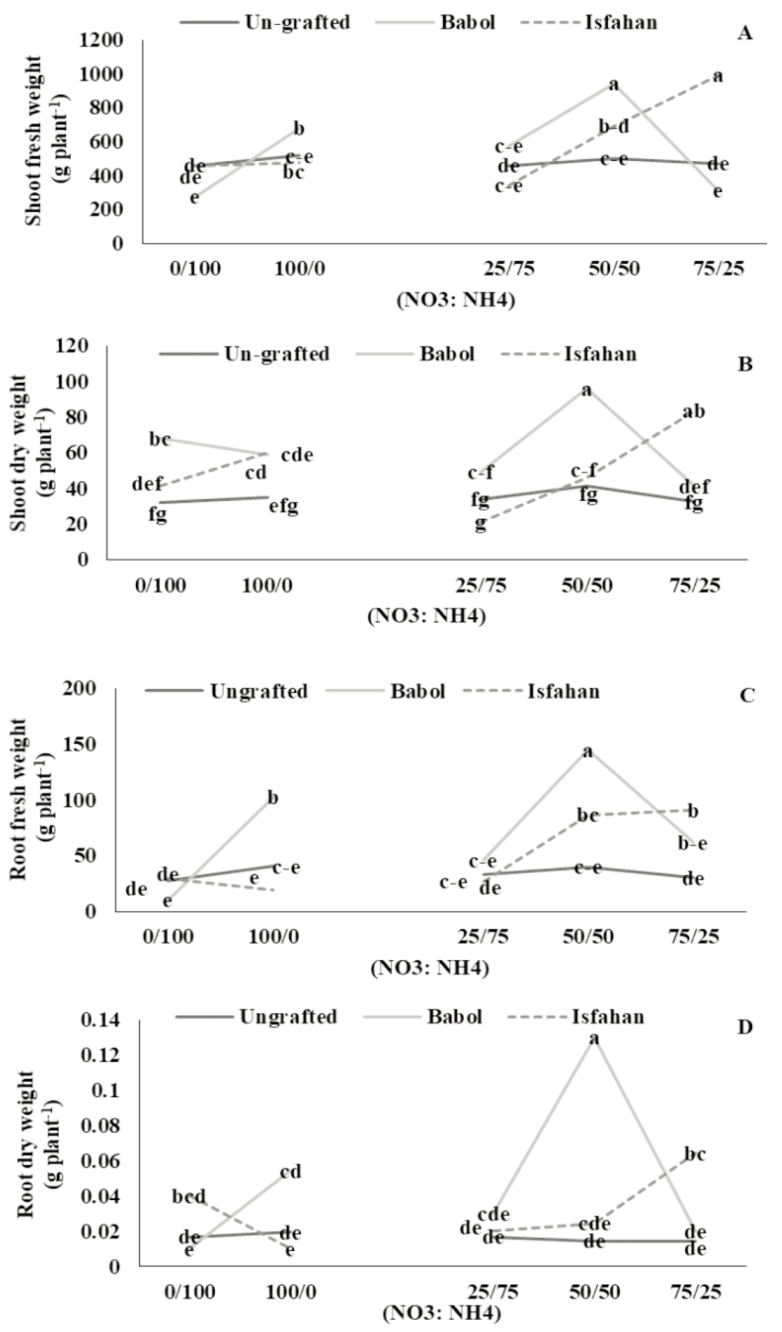

Fig. 2 - The interaction effect of different rootstocks and $\mathrm{NO}_{3}: \mathrm{NH}_{4}$ ratio on $\mathrm{A}$ ) shoot fresh weight, $\mathrm{B}$ ) shoot dry weight, C) root fresh weight and D) root dry weight.

leaves and nodes was seen in the ungrafted plants. These findings were in line with the increase in shoot length, which was higher in treatments with increased $\mathrm{NO}_{3}{ }^{-} / \mathrm{NH}_{4}{ }^{+}$ratio for grafted plants.

Photosynthesis was more significant in both grafted cucumbers in all the $\mathrm{NO}_{3}{ }^{-} / \mathrm{NH}_{4}{ }^{+}$ratio compared with the ungrafted plant, and it seemed that it is not related to the changes of the greenness index (Fig. $4 \mathrm{~A})$. The greenness index did not change between treatments significantly, except for the high increase in Babol from the50/50 $\mathrm{NO}_{3}{ }^{-} / \mathrm{NH}_{4}{ }^{+}$ratio. Furthermore, the photosynthesis rate increased in the $50 / 50 \mathrm{NO}_{3}{ }^{-} / \mathrm{NH}_{4}{ }^{+}$ratio in the ungrafted cucumber (Fig. 4B).

Transpiration in all the rootstock was increased by the $25 / 75 \mathrm{NO}_{3}^{-} / \mathrm{NH}_{4}^{+}$and decreased with increasing $\mathrm{NO}_{3}{ }^{-} / \mathrm{NH}_{4}{ }^{+}$ratio in the nutrient solution. It seemed

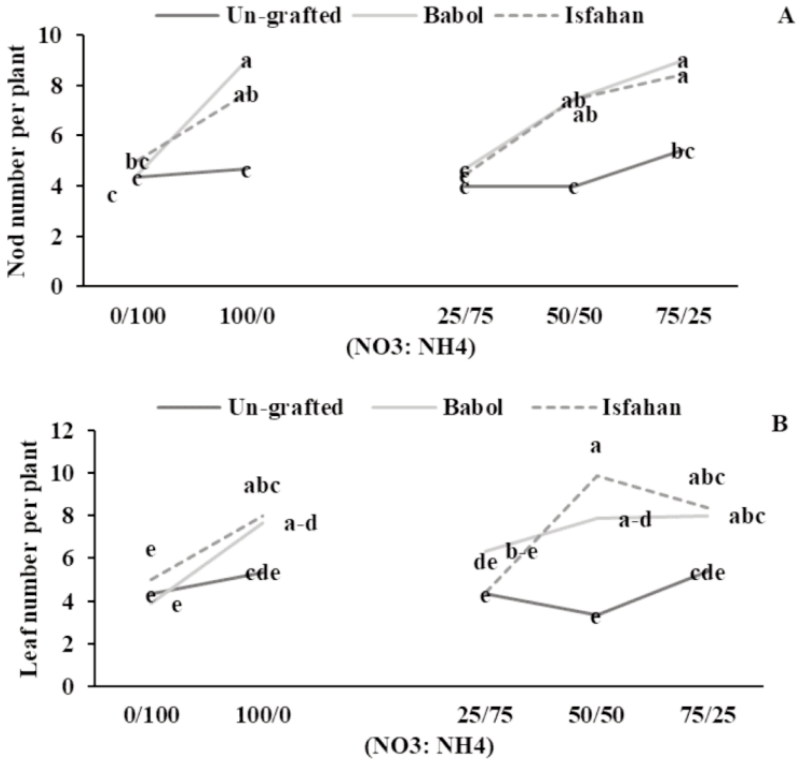

Fig. 3 - The interaction effect of different rootstocks and $\mathrm{NO}_{3}: \mathrm{NH}_{4}$ ratio on $\mathrm{A}$ ) number of leaves and $\mathrm{B}$ ) number of nodes.
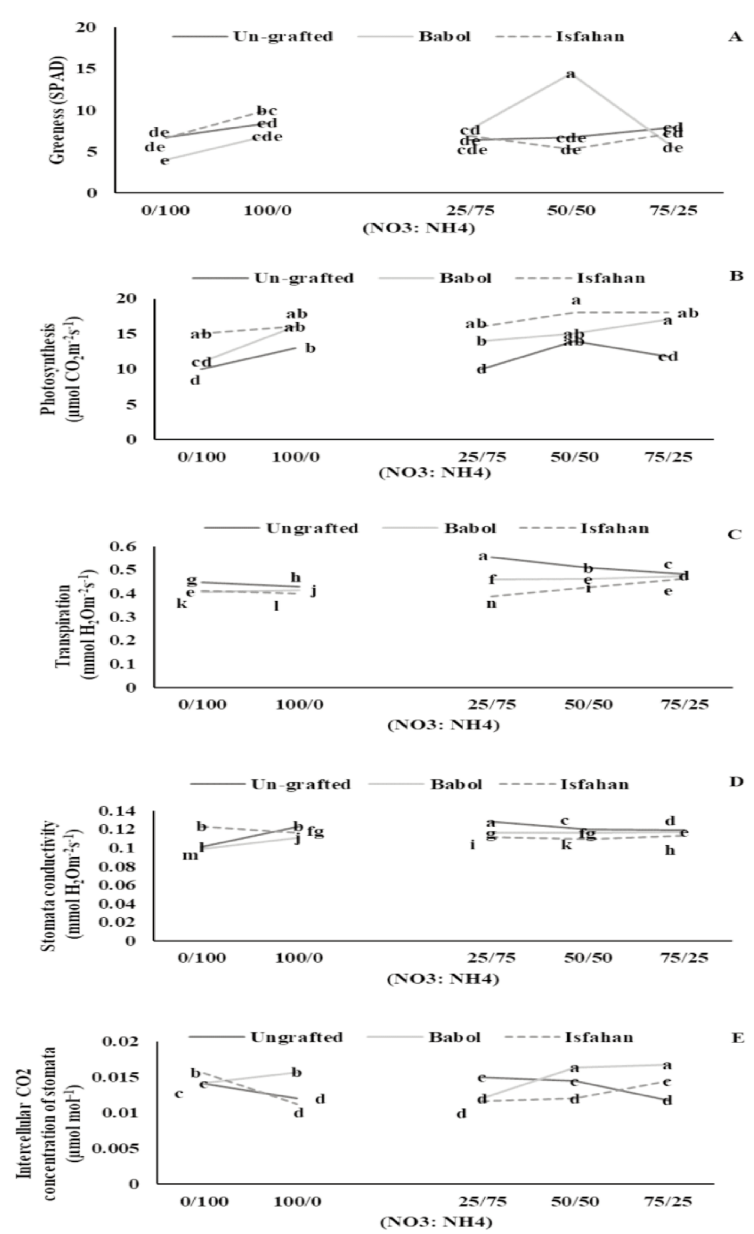

Fig. 4 - The interaction effect of different rootstocks and $\mathrm{NO}_{3}: \mathrm{NH}_{4}$ ratio on A) Greenness (SPAD), B) photosynthesis, C) transpiration D) stomata conductivity, and E) intercellular $\mathrm{CO}_{2}$ concentration of stomata. 
that by increasing transpiration in all plants stomata conductivity was increased by the $25 / 75 \mathrm{NO}_{3}{ }^{-} / \mathrm{NH}_{4}{ }^{+}$ treatment (Fig. 4C).

Stomata conductivity was highly raised in the Isfahan rootstock and the ungrafted plants (Fig. 4D). The stomata conductivity was enhanced in the ungrafted cucumber, especially at 25/75 $\mathrm{NO}_{3}{ }^{-} / \mathrm{NH}_{4}{ }^{+}$. Conversely, the $\mathrm{CO}_{2}$ concentration in the stomata reduced in the $25 / 75 \mathrm{NO}_{3}-/ \mathrm{NH}_{4}{ }^{+}$and increased with $\mathrm{NO}_{3}{ }^{-}$increment in the nutrient solution (Fig. 4E).

Phenol exudate of the root was highest in 25/75 $\mathrm{NO}_{3}^{-} / \mathrm{NH}_{4}^{+}$and decreased by increasing the $\mathrm{NO}_{3}^{-}$portion (Fig. 5A). It was highest in the ungrafted compared to the grafted cucumber plants. The highest proline content was seen in the 100/0 and the 25/75 $\mathrm{NO}_{3}{ }^{-} / \mathrm{NH}_{4}{ }^{+}$and decreased by increasing the $\mathrm{NO}_{3}{ }^{-}$concentration (Fig. 5B).

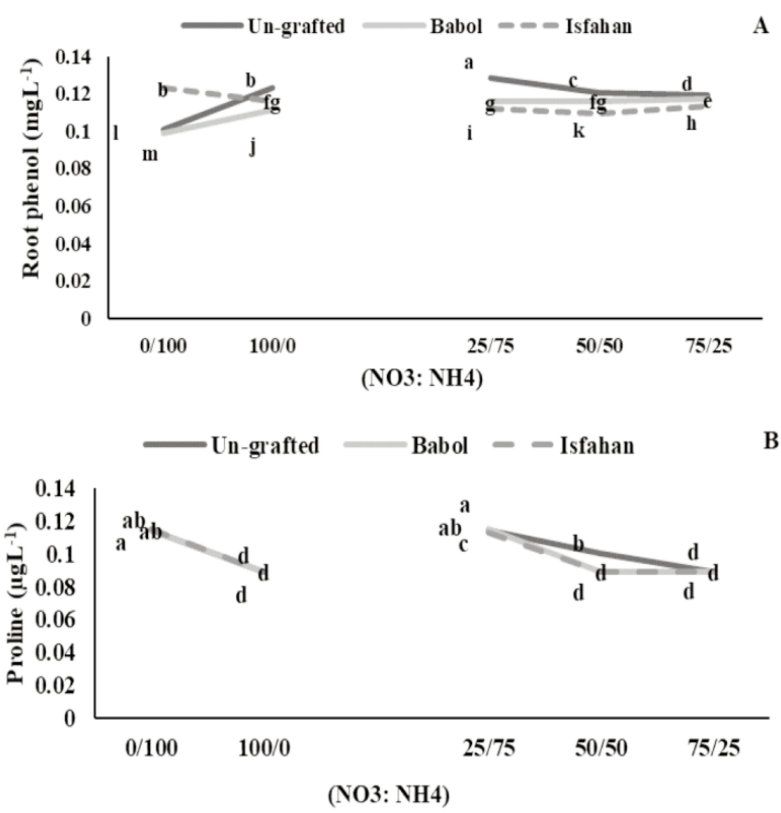

Fig. 5 - The interaction effect of different rootstocks and $\mathrm{NO}_{3}: \mathrm{NH}_{4}$ ratio on $\mathrm{A}$ ) proline and $\mathrm{B}$ ) root phenol.

Nitrate reductase activity was highest in the 25/75 $\mathrm{NO}_{3}^{-} / \mathrm{NH}_{4}^{+}$and was reduced by increasing the $\mathrm{NO}_{3}$ portion. The lowest $\mathrm{NO}_{3}$ - concentration was recorded by the $0 / 100$ and the $25 / 75 \mathrm{NO}_{3}{ }^{-} / \mathrm{NH}_{4}{ }^{+}$. Nitrate concentration was higher in the $0 / 100$, and $100 / 0$ $\mathrm{NO}_{3} / \mathrm{NH}_{4}$ and was the same in between grafting plants in $25 / 75$ and $50 / 50 \mathrm{NO}_{3} / \mathrm{NH}_{4}$ (Fig. 6B). The amino acid was higher in grafted cucumber, especially in $5 / 75$ and $50 / 50 \mathrm{NO}_{3} / \mathrm{NH}_{4}$. Protein content was higher in $50 / 50 \mathrm{NO}_{3} / \mathrm{NH}_{4}$ in all rootstock and ungrafted (Fig. 6A).
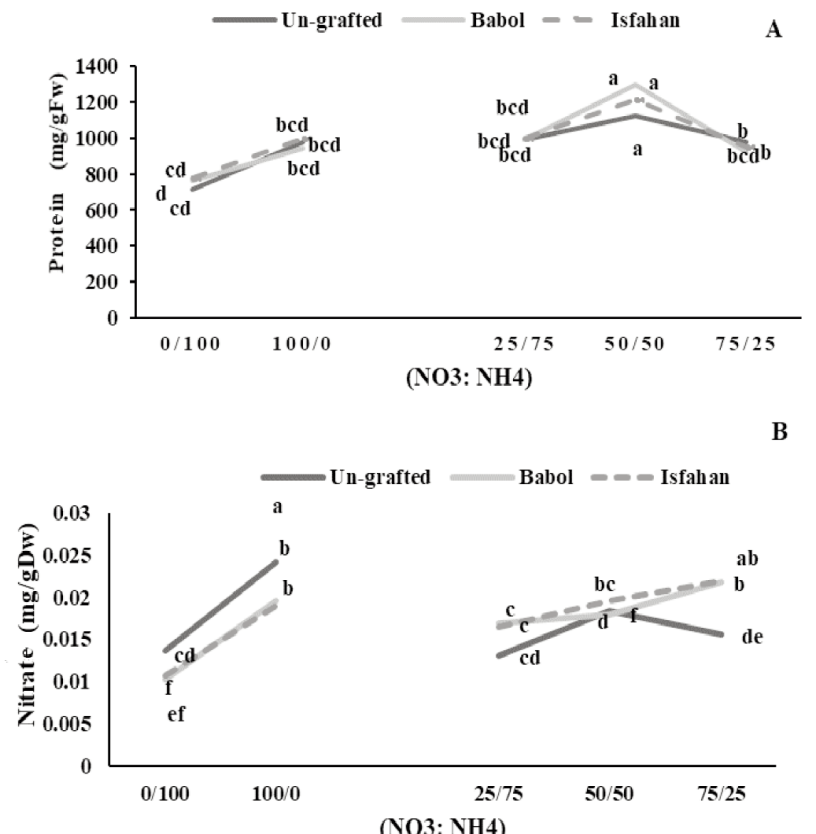

B
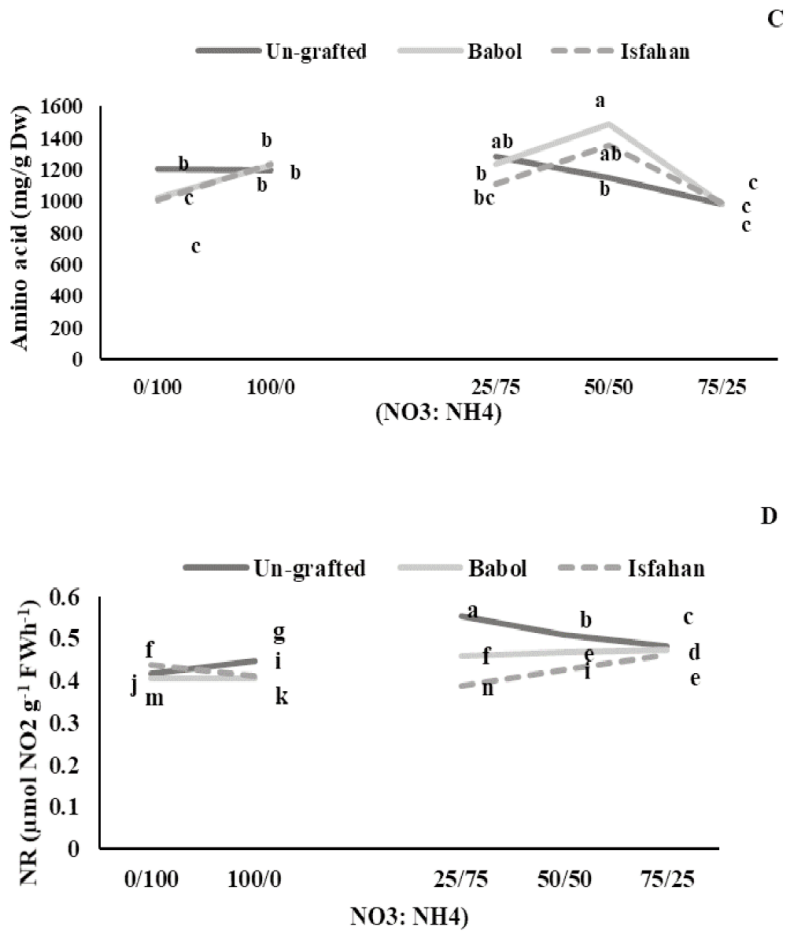

Fig. 6 - The interaction effects of different rootstocks and $\mathrm{NO}_{3}: \mathrm{NH}_{4}$ ratio on $\mathrm{A}$ ) protein, B) nitrate and C) amino acid D) nitrate reductase (NR) activity.

It seemed that the most nutrient absorption was recorded by the Babol and the Isfahan rootstock, especially in the $100 / 0,75 / 25$ followed by the $50 / 50$ $\mathrm{NO}_{3}{ }^{-} / \mathrm{NH}_{4}+$ for $\mathrm{N}$ and $\mathrm{K}$ (Fig. 7). Conversely, the highest $\mathrm{Ca}$ absorption was recorded by the $50 / 50 \mathrm{NO}_{3}{ }_{3}$ $/ \mathrm{NH}_{4}{ }^{+}$and to lesser extent by the $75 / 25 \mathrm{NO}_{3}{ }^{-} / \mathrm{NH}_{4}^{+}$. 
The $\mathrm{Mg}$ and $\mathrm{P}$ absorption were less absorbed, but highest in the Babol rootstock.

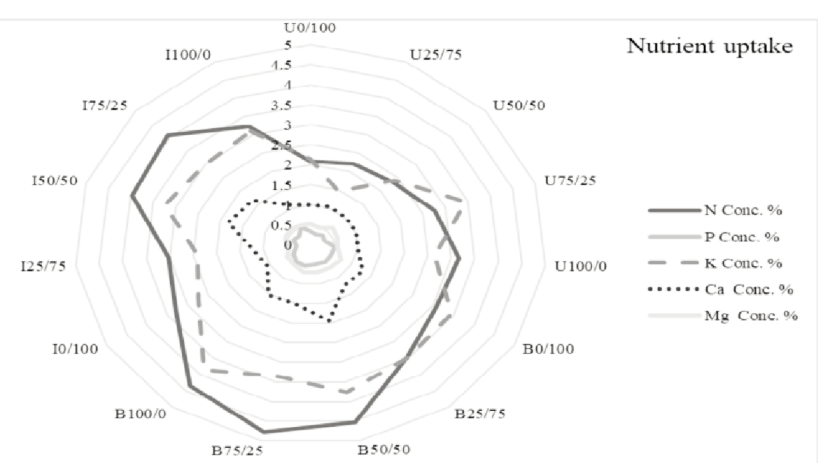

Fig. 7 - The effects of different rootstocks on nutrients (N, P, K, $\mathrm{Ca}$ and $\mathrm{Mg}$ ) absorption in different $\mathrm{NO}_{3}: \mathrm{NH}_{4}$ ratio.

\section{Discussions and Conclusions}

The effect of $\mathrm{NO}_{3}{ }^{-} / \mathrm{NH}_{4}{ }^{+}$and grafting on the cucumber growth

A wide range of morphological and physiological characteristics are influenced by scions, rootstocks and their interactions (He et al., 2009). In this study, it was observed that growth in terms of shoot and root fresh and dry weights, root and shoot lengths, numbers of node and leaves were increased by the 75/25 treatment. However, some parameters were not significantly affected. All the growth parameters were improved by the $75 / 25$ treatment in Isfahan rootstock. On the other hand, the best result in plant growth improvement was seen in the 50/50 treatment for Babol. These results revealed that different rootstock act differently in different $\mathrm{NO}_{3}-\mathrm{NH}_{4}{ }^{+}$ratio to promote growth. In all the growth parameters, the ungrafted cucumber was lower than the grafted ones and Babol showed a better or similar increase than Isfahan rootstock. When using $\mathrm{NO}_{3}{ }^{-}$or $\mathrm{NH}_{4}{ }^{+}$alone, plant growth was not significantly different except for the numbers of node and leaves and root length in the grafted cucumber following application of $\mathrm{NH}_{4}^{+}$ alone. It noted that the use of both sources of $\mathrm{N}$ individually was not economical. Less plant growth was seen in the ungrafted cucumber by using $\mathrm{NO}_{3}{ }^{-}$or $\mathrm{NH}_{4}^{+}$ alone compared to the grafted cucumber.

Different rootstocks have different root size and different absorbance abilities which can affect vegetative growth rates. Rootstocks improve photosynthetic ability and increase yield in grafted plants (Massai et al., 2004). Rootstocks improve growth in plant by improving nutrient uptake, hormonal status and root growth (Lee et al., 2010). Grafting, especially Babol rootstocks, contributed to better vegetative growth of 'Dominos' due to higher root distribution, perhaps resulting in more nutrient uptake. It should be considered that increasing number of nodes is a sign for more yield because the flower initiate in nodes so the more node means more flowers and fruits as obtained with grafted cucumber.

The effect of $\mathrm{NO}_{3}^{-} / \mathrm{NH}_{4}^{+}$and grafting on the metabolism of cucumber

Results revealed that grafting on the Isfahan and Babol showed the same effect on $\mathrm{N}$ metabolism, i.e., $\mathrm{NR}$ activity decreased and $\mathrm{NO}_{3}^{-}$concentration increased in plants treated with the 75/25 and the $100 / 0 \mathrm{NO}_{3}{ }^{-} / \mathrm{NH}_{4}{ }^{+}$. Protein and amino acids contents of leaves was increased at the 50/50 treatment in grafted cucumber and protein showed the same trend like amino acid. It can be concluded that the healthiest cucumber plant was obtained from the 50/50 treatment in the grafted cucumber although the most nitrate metabolism was achieved by treatment $75 / 25$ $\mathrm{NO}_{3}{ }^{-} / \mathrm{NH}_{4}{ }^{+}$. Despite the effect of rootstock on growth, it was seen that the rootstock has no difference in the metabolism $\mathrm{N}$ in the cucumber plants. The other reason for the promotion of plant growth by changing the $\mathrm{NO}_{3}{ }^{-} / \mathrm{NH}_{4}{ }^{+}$ratio could be that after $\mathrm{NR}$ reduced $\mathrm{NO}_{3}^{-}$to nitrite, it was changed to ammonium, and amino acids were produced, which can later combine to produce proteins (Haghighi et al., 2012). On the other hand, nitrate through producing active forms of cytokinins, as an osmolyte in vacuoles, stimulates leaf function and growth, causing cell extension and improved growth (Wang et al., 2008). Increasing root length and cytokinin production helped the plant to absorb more water and nutrients to improve vegetative growth (Haghighi et al., 2016 a).

The effect of $\mathrm{NO}_{3}{ }^{-} / \mathrm{NH}_{4}{ }^{+}$and grafting on the stress photosynthesis traits of cucumber

Photosynthesis was not affected by $\mathrm{N}$ ratio but increased by grafting. Stomata conductance, internal $\mathrm{CO}_{2}$ of stomata and transpiration increased with increasing $\mathrm{NO}_{3}{ }^{-} / \mathrm{NH}_{4}{ }^{+}$ratio and was reduced by grafted cucumber. It seemed changes in photosynthesis traits were more related to stomata status, which can be associated with the rootstock.

Photosynthesis was improved with grafting due to an efficient root system of the rootstock with regards to nutrient uptake compared to the ungrafted plants 
(Lee et al., 2010). Furthermore, more vigorous rootstocks could absorb more water and nutrients. Consequently, photosynthesis improved when these rootstocks were used compared to non-grafted plants as reported previously by Haghighi et al. (2016 b). In all $\mathrm{NO}_{3}^{-} / \mathrm{NH}_{4}^{+}$ratios, grafting reduced stomata conductivity, which resulted in lower transpiration and improved water use efficiency so plants could deal with challenged conditions more efficiently (Duan et al., 2001).

In conclusion, the performance of the different cucumber plant accessions used as rootstocks i.e. nutrient absorption and growth parameters varied. The two accessions used in this study i.e. Isfahan and Babol responded similarly to $\mathrm{N}$ metabolism and photosynthesis traits. Therefore, it seems that different rootstock has the same physiology but different growth pattern due to their pre-existing genetic differences. More noticeably, we found that, shoot and root fresh and dry weights, root and shoot lengths, nodes, and number of leaves were increased by the $75 / 25$ ratio of $\mathrm{NO}_{3}{ }_{3} / \mathrm{NH}_{4}{ }^{+}$. Grafting on the Isfahan and Babol increased nitrate reductase activity and $\mathrm{NO}_{3}$ concentration, protein content, amino acids content of leaves and photosynthesis parameters. Our findings suggested that the grafting 'Dominos' on Babol endemic rootstock using 50/50 $\mathrm{NO}_{3}{ }^{-} / \mathrm{NH}_{4}{ }^{+}$ratio achieved better vegetative growth, which may result in better yield.

\section{References}

AHMADI A., SIOSEMARDEH A., 2005 - Investigation on the physiological basis of grain yield and drought resistance in wheat: leaf photosynthetic rate, stomatal conductance, and non-stomatal limitations. - Int. J. Agric. Biol., 7: 807-811.

ATANASOVA E., 2008 - Effect of nitrogen sources on the nitrogenous forms and accumulation of amino acid in head cabbage. - Plant Soil Environ., 54(2): 66.

BATES L.S., WALDREN R.P., TEARE I.D., 1973 - Rapid determination of free proline for water-stress studies. - Plant Soil, 39: 205-207.

BRADFORD M.M., 1976 - A rapid and sensitive method for the quantitation of microgram quantities of protein utilizing the principle of protein-dye binding. - Anal. Biochem., 72: 248-254.

CAUSIN H.F., TREMMEL D.C., RUFTY T.W., 2004 - Growths nitrogen uptake, and metabolism in two semiarid shrubs grown at ambient and elevated atmospheric $\mathrm{CO}_{2}$ concentrations effects of nitrogen supply and source. - Am. J. Bot., 91(4): 565-572.

CAZETTA J.O., VILLELA L.C.V., 2004 - Nitrate reductase activity in leaves and stems of tanner grass (Brachiaria radicans Napper). - Sci. Agric., 61(6): 640-648.

COLLA G., ROUPHAEL Y., CARDARELLI M., SALERNO A., REA E., 2010 - The effectiveness of grafting to improve alkalinity tolerance in watermelon. - Environ. Exp. Bot., 68: 283-291.

DADASHPOUR A., SHEKAFANDEH A., OLADI R., 2017 Anatomical and morphological changes in scions of some olive grafting combinations under water deficit. Hortic. Sci., 31(4): 281-288.

DUAN B., RAN F., ZHANG X., ZHANG Y., KORPELAINEN H., LI $\mathrm{CH} ., 2001$ - Long-term acclimation of mesophyll conductance, carbon isotope discrimination and growth in two contrasting Picea asperata populations exposed to drought and enhanced UV-b radiation of tree years. Agric. For. Meteorol., 151: 116-126.

EL-ABAGY H.M., EL-TOHAMY W.A., ABDOL-MAWGOUD A.M.R., ABOUHUSSEIN SH., 2014 - Effect of different amino acid sources and application rates on yield and quality of onion in the newly reclaimed lands. - Middle East J. Agric. Res., 3(1): 81-88.

ESTAN M.T., MARTINEZ-RODRIGUEZ M.M., PEREZ-ALFOCEA F., FLOWERS T.J., BOALRIN M.C., 2005 - Grafting raises the salt tolerance of tomato through limiting the transports of sodium and chloride to the shoot. - J. Exp. Bot., 56: 703-712.

FERNANDEZ-NAVA Y., MARANON E., SOONS J., CASTRILLON L., 2010 - Denitrification of fight nitrate on centration waste water in alternative carbon sources. - J. Hazard. Mater., 173: 682-688.

GORETA BAN S., ŽANIĆ K., DUMIČIĆ G., RASPUDIĆ E., VULETIN SELAK G., BAN D., 2014 - Growth and yield of grafted cucumber in soil infested with root-knot nematodes. - Chilean J. Agric. Res., 74(1): 29-34.

HAGHIGHI M., HEIDARIAN S., TEIXEIRA J., SILVA DA A., 2012 - The effect of titanium amendment in- $n$-withholding nutrient solution on physiological and photosynthesis attributes and micro-nutrienut uptake of tomato. - Biol. Trace Elem. Res., 150: 381-390.

HAGHIGHI M., MOHAMMADNIA S., PESSARAKLI M., 2016 a - Effects of mycorrhiza colonization on growth, root exudates, antioxidant activity and photosynthesis trait of cucumber grow in Johnson modified nutrient solution. - J. Plant Nutr., 39: 2079-2091.

HAGHIGHI M., SHEIBANIRAD A., PESSARAKLI M., 2016 b Cucurbits grafting: Methods, physiology, and responses to stresses, pp. 255-272. - In: PESSARAKLI M. (ed.) Handbook of cucurbits, growth, cultural practices, and physiology. CRC Press, Boca Raton, FL, USA, pp. 594.

HAHNE K., SCHUCH U.K., 2006 - Nitrogen form and concentration affect nitrogen leaching and seedling growth of Prosopis velutina. - HortSci., 41(1): 239-243.

HE Y., ZHU Z.J., YANG J., NI X.L., ZHU B., 2009 - Grafting increases the salt tolerance of tomato by improvement of photosynthesis and enhancement of antioxidant enzymes activity. - Environ. Exp. Bot., 66: 270-278.

JONES D.L., SHANNON D., JUNVEE-FORTUNE T., FARRAR 
J.F., 2005 - Plant capture of free amino acids is maximized under high soil amino acid concentrations. - Soil Biol. Biochem., 37: 179-181.

KASHI A.K., SALEHI MOHAMMADI R., JAVAHKPOUR R., 2008 - Technology grafting in cultivation and production of vegetables. - Tehran University Press, Tehran, Iran.

KESHAVARZI M., SHEKAFANDEH A., 2019 - The responses of enzymatic and non- enzymatic antioxidants systems of scion on different rootstocks under water stress deficit. - Adv. Hort. Sci., 33(2): 161-170.

LEE J.M., 1994 - Cultivation of grafted vegetables. I. Current status grafting methods and benefits. - Hortic. Sci., 29: 235-239.

LEE J.M., KUBOTA C., TSAO S.J., BIE Z., HOYOSECHEVARRIA P., MORRA L., ODA M., 2010 - Current status of vegetable grafting diffusion grafting techniques automation. - Hortic. Sci., 127: 93-105.

LEE J.M., ODA M., 2003 - Grafting of herbaceous vegetable and ornamental crops. - Hortic. Rev., 28: 61-124.

MARSCHNER P., 2012 - Marschner's mineral nutrition of higher plants. - Academic Press, San Diego, CA, USA, pp. 672.

MASSAI R., REMORINI D., TATTINI M., 2004 - Gas exchange, water relations and osmotic adjustment in two scion/rootstock combinations of Prunus under various salinity concentrations. - Plant Soil, 259: 153-162.

MOTAMEDI M., HAGHIGHI M., GOLI A.H., 2019 Physiological changes of sweet and hot peppers invegetative and reproductive growth stages treated by $\mathrm{Ca}$ and $\mathrm{H}_{2} \mathrm{O}_{2}$ under unforeseen heat stresses. - Sci. Hortic., 249: 306-313.

MURILLO-AMADOR B., YAMADA S., YAMAGUCHI T., RUEDA PUENTE E., ÁVILA SERRANO N., GARCÍA HERNÁNDEZ J.L., LÓPEZ AGUILAR R., TROYO DIÉGUEZ E., NIETO GARIBAY A., 2007 - Influence of calcium sili- cate on growth physiological parameter and mineral nutrition in two legume species under salt stress. - J. Agron. Crop Sci., 193(6): 413-421.

NIU G., GU M., RODRIGUEZ D., 2011 - Response of Sophora secundiflora to nitrogen form and rate. - Hort. Sci., 46(9): 1303-1307.

POGONYI A., PEK Z., HELYES Z., LUGASI L., 2005 - Effect of grafting on the tomatoes yield quality and main fruit components in spring forcing. - Acta Aliment., 34: 453462.

ROUPHAEL Y., CARDARELLI M., COLLA G., REA E., 2008 Yield, mineral composition, water relations and water use efficiency of grafted mini-water melon plants under deficit irrigation. - Hort. Sci., 43: 730-736.

SHARIFI F.M., HEIDARI M., MOVAHEDIRAD Z., 2014 Measuring the density of calcium and magnesium elements in pistachio leaf by ICP modern method and comparing it with titration methods and atomic absorption. - IJABBR, 2(4): 1328-1331.

SHARIFI M., REEKIE J., HAMMERMEISTER A., ZAHIDUL ALAM M., MACKEY T., 2016 - Effect of over crops on yield and leaf nutrient concentration is an organic honeycrisp apple (Malus domestica 'Honey crisp') orchard in Nova Scotia, Canada. - Hort. Sci., 51(11): 1378-1383.

SIDDIQI M.Y., BHUPINDER M., XIANGJIA M., ANTHONY G., 2002 - Effects of ammonium and inorganic carbone enrichment on growth and yield of a hydroponic tomato crop. - J. Plant Nutri. Soil Sci., 165(2): 261-272.

WANG H., WU L., ZHU Y., TAO Q., 2008 - Growth, nitrate accumulation, and macro nutrient concentration of pakchoi as affected by external nitrate-n: amino acid-n ratio. - J. Plant Nutr., 31: 1789-1799.

XING S., WANG J., ZHOU Y., BLOSZIES S.A., TU C., HU S., 2015 - Effects of $\mathrm{NH}_{4}{ }^{+} \mathrm{N} / \mathrm{NO}_{3}{ }^{-} \mathrm{N}$ ratios on photosynthetic characteristics, dry matter yield and nitrate concentration of spinach. - Expl. Agric., 51(1): 151-160. 